\title{
Reasons for Inadequate Vaccination after Splenectomy
}

\author{
Marko Tanasković1, Slobodan Jankovićc ${ }^{2,3}$, Bozidar Odalovićc,5, Nedim Hamzagić ${ }^{6}$ \\ ${ }^{1}$ Community Health Center Gracanica, Gracanica, Serbia \\ ${ }^{2}$ Clinical Center Kragujevac, Department of Clinical Pharmacology,Kragujevac, Serbia \\ ${ }^{3}$ Faculty of Medical Sciences Kragujevac, University of Kragujevac, Kragujevac, Serbia \\ ${ }^{4}$ Clinical Center Pristina-Gracanica, Department of Surgery, Gracanica, Serbia \\ ${ }^{5}$ Faculty of Medicine Pristina-Kosovska Mitrovica, University of Pristina, Kosovska Mitrovica, Serbia \\ ${ }^{6}$ Community Health Center Tutin, Department of Nephrology, Tutin, Serbia
}

\section{SUMMARY}

The aim of this study was to analyze the reasons why the guidelines for post-splenectomy vaccination are not being followed. Considering that vaccination reduces the risk of overwhelming post-splenectomy infection, it is important to determine the reasons for inadequate vaccination after splenectomy.

Our research was a qualitative study based on interviews with six surgeons, one general practitioner and three patients who underwent splenectomy, and on the review of patient's medical charts and discharge summaries.

This study has shown that health care team and patients lack sufficient knowledge about postsplenectomy vaccination. In addition, the study has shown that splenectomy registers, medical bracelets and up-to-date vaccination cards still have not become part of our current practice.

Our study has shown that patient education and health care team education is crucial to follow the guidelines for post-splenectomy vaccination, which is similar to most other reports.

In order to increase the level of post-splenectomy vaccination, we need to upgrade the education of health care teams and patients. Moreover, we need to start using splenectomy registers, medical bracelets and up-to-date vaccination cards.

Key words: splenectomy, vaccination, qualitative, education 


\section{INTRODUCTION}

Surgical removal of the spleen (splenectomy) is performed through emergency surgery due to trauma, and can also be performed for the treatment or diagnosis of malignant and benign diseases. Postsplenectomy sepsis is one of the most serious complications after splenectomy. Pneumococci, meningococci and Haemophilus influenzae are the most common pathogens that cause post-splenectomy sepsis. Almost all of pharmacotherapeutic handbooks recommend vaccination as a preventive measure for these complications two weeks prior to surgery or a week after surgery in emergencies when there is no time for vaccination prior to splenectomy. The use of vaccines is becoming increasingly important due to the appearance of antibiotic-resistant strains of pneumococci. Therefore, all patients before/after splenectomy should be vaccinated against pneumococcus, meningococcus and Haemophilus influenzae to be protected against post-splenectomy sepsis.

While information that all patients should be vaccinated after splenectomy has been known since 1970, there are still patients who are not vaccinated or revaccinated after splenectomy. One study in the Netherlands found that out of 130 patients who underwent splenectomy only $103 \quad(79.2 \%)$ were vaccinated against pneumococcus (1). The percentage of patients vaccinated against meningococcus and Haemophilus influenzae was even lower $(27 \%$ and $32 \%$, respectively). These results are unsatisfactory, especially when we take into account the efforts of the professional community to understand the importance of post-splenectomy vaccination. As a cause of these results, the researchers considered inadequate patient education about the importance of vaccination and post-splenectomy risks. Another similar research conducted in the UK has shown that the percent of patients who were vaccinated against pneumococci after splenectomy was only $31 \%$, which is another proof that the recommendations are not implemented in practice. Researches, as the causes of these results, considered poor commitment of health care team to educate the patients and poor commitment of patients to understand the importance of vaccination (2).

This study will help to determine the reasons why patients were not vaccinated after splenectomy. Considering that patients who are not vaccinated are at much higher risk of mortality versus vaccinated patients, it is important to resolve any omissions and increase the level of vaccine implementation in these patients.

\section{MATERIAL AND METHODS}

\section{Study design}

This study is a qualitative research as the subject is very complex and we need to know more about the reasons why patients are not vaccinated after splenectomy. The study was conducted using semi-structured interviews at the Department of Surgery at the Hospital Center Kosovska Mitrovica, Department of Surgery at the Clinical Centre PristinaGracanica and Community Health Center Gracanica. We interviewed surgeons with experience in performing splenectomy $(\mathrm{n}=6)$, primary care physicians $(n=1)$ and patients who underwent splenectomy $(n=3)$.

Interview: The interview consisted of 15 structured questions with an unstructured part to record opinions of doctors and patients that were not covered by questions. The focus was on the patient social status, patient education, the availability of vaccines on the market, physician education, financial problems, cooperation between health care institutions but also the commitment of doctors to explain to the patient the importance of vaccination after splenectomy. All interviews were conducted face to face. Interview protocol was developed to enable patients to describe in detail the reasons why they did not receive vaccines and to give the physicians an opportunity to describe their experiences related to this topic. The interviews were recorded after signing the consent. We removed all the parts of the interview that could reveal the identity of participants. All participants were offered the opportunity, if they wanted, to double-check all audio material recorded during interviews. The participants were explained the role of the study as well as how the data will be collected and analyzed. Interviews lasted an average of 10 minutes and were recorded in doctor's office, alone with each participant and without any obstruction. The study was conducted in the period from March 2015 to July 2015.

Examining the medical records (hospital protocols, patient records, and discharge summaries) in Hospital Center Kosovska Mitrovica and Clinical Centre Gracanica, we identified the number of patients who underwent splenectomy in the last 5 
years and what vaccination patients received after splenectomy.

\section{Criteria for inclusion in to the study:}

Surgeons who had years of experience in performing splenectomy (at least 5 years), primary care physicians and patients who underwent splenectomy.

\section{Criteria for exclusion from the study:}

The study did not include patients with disturbed cognitive functions.

\section{Data analysis}

To analyze the data we have used inductive thematic analysis. All the interviews were transcribed into the written form. At the beginning, we made a start list of potential codes according to terminology used by participants during the interview. We read and reread all the data, until we became familiar with the material. Then we made an initial list of codes which were then combined and compared to define and name the themes. We reviewed the themes to be sure that the current themes relate back to the data we collected. The next step was writing the detailed report.

\section{Approval}

The study was approved by the Ethics Committee of the Hospital Center Kosovska Mitrovica, Ethics Committee of Clinical Centre Pristina-Gracanica and Community Health Center Gracanica.

In addition to the interview, Ethics Committee has also approved an insight into the files of patients who underwent splenectomy in the previous 5 years, in order to determine the percentage of patients who were vaccinated after splenectomy.

\section{RESULTS}

Three patients, six surgeons and one primary care physician finally participated. Forty-seven patients underwent splenectomy in the past five years at the Clinical Centre Pristina and Hospital Center
Kosovska Mitrovica. Forty patients were vaccinated only against pneumococci, two patients were not vaccinated at all, whereas five patients were lost to follow up, because there were no data in their medical files. In each patient's discharge summary was mentioned that patients should receive only pneumococcal vaccine, but it was not mentioned whether the patients should receive vaccination for Neisseria meningitides and Haemophilus influenzae. Also, the need for future revaccination was not mentioned. None of the patients received written information about post-splenectomy risks, medical alert bracelet or up-to-date vaccination card. There were no splenectomy registers.

The interviews were approximately 10 minutes long. The major themes identified are described below.

\section{Health care team education}

In Serbia, post-splenectomy vaccination may be done in community health centers as well as at the hospital and clinical centers where splenectomy was performed. Post-splenectomy vaccination in community health centers is led by general practitioner. General practitioners are usually not familiar with this subject and they do not pay much attention to post-splenectomy vaccination, because splenectomy is a rare surgery.

"How much general practitioners recognize the importance of mandatory vaccination, and how much they are familiar with the problem of postsplenectomy sepsis is questionable."

"Yes, they (general practitioners) are less familiar with these issues."

The general practitioner we interviewed knew about post-splenectomy risks and knew only about the use of pneumococcal vaccine in patients who underwent splenectomy. However, he also said that he had not met such patients yet.

For those patients who were vaccinated at community health centers, it is important that general practitioners are familiar with this topic. Participants agreed that we need to educate general practitioners more.

"I think we need better training of doctors and attending physicians."

Education would be helpful not only for general practitioners but also for surgeons, epidemiologists and other health care team members, even those with experience. 
"Perhaps we, as doctors, also make mistakes because we do not pay enough attention to vaccination and possible deterioration like the postsplenectomy sepsis, as in cases of spleen injuries"

Only one of the surgeons we interviewed mentioned meningococcal and pneumococcal vaccine, but he did not know about the use of Haemophilus influenzae vaccine in post-splenectomy patients. All other surgeons knew that patients after splenectomy should receive pneumococcal vaccine but none of them knew about the use of meningococcal and Haemophilus influenzae vaccines after splenectomy.

"Well, here specifically, only against pneumococcus." Pneumovax."

"We recommended all the patients to receive

All surgeons told us that they recommended their patients to be vaccinated after splenectomy, although some surgeons admit that their colleagues do not recommend their patients to get vaccinated, because they think that patient's immune system is compromised and vaccines cannot help those patients.

"Even the attitudes of some fellow surgeons are that patients do not need the vaccine after splenectomy."

"Attitudes are different. Some believe that patients should not be vaccinated. I consider that even a smaller percentage of surgeons actually believe they (patients) should be vaccinated."

\section{Patient's education}

Participants also indicated that patient's education about post-splenectomy risks is at a very low level and has a crucial role in explaining the reasons why patients are not vaccinated after splenectomy.

Some surgeons believe that patients are not that interested in their health if they feel well after the surgery.

"Well, I believe there is a poor health education of population and I have to say the main reason is that after splenectomy all patients mostly feel healthy, therefore they think there is no need to visit their doctor."

"I believe that a number of patients who underwent surgery in Pristina did not receive this vaccine because they felt good."

Some participants believe that patient education is the main reason for vaccination failure.
"Well, in any case, and in this regard, the patient education is crucial."

Surgeons mainly complain that patients do not go to the doctor's for control examination after surgery.

"Poor monitoring and patient's not seeing a doctor for control examination."

“He/she (patient) will appear perhaps once for control examination and after that you will rarely see him/her (patient)."

Some surgeons believe that patients have some kind of resistance to get vaccinated because they believe it will not help them at all.

"There is resistance in patients even for routine vaccination of their children, let alone for this (postsplenectomy vaccination).

While doctors claim that they have explained patients the existence of post-splenectomy risks to patients, patients we interviewed claimed the opposite. When we asked the patients if they knew about post-splenectomy risks their answers were the following:

"No, I do not know."

"I am not sure."

When asked if they got information from their doctor, patients said either "No", or they were confused or not sure about the risks after splenectomy.

None of the patients we interviewed received written information about risks and precautions after splenectomy. Also, none of the patients received upto-date vaccination card or medical alert bracelet.

Patients we interviewed told us about the recommendation they received from their health care team. Firstly, the patient knew about all three vaccines he should receive, but still he received only pneumococcal vaccine, because the doctor told him that pneumococcal vaccine was the most important one. Secondly, the patient did not know anything about the post-splenectomy risks and vaccines, so she did not receive any vaccine after splenectomy. Thirdly, the patient knew only for pneumococcal vaccine so she received only this vaccine.

\section{DISCUSSION}

This study explored doctors' and patients' views about the reasons that influenced inadequate vaccination among patients who underwent splenectomy. Our findings suggest that in this group a health care team education and patient' education 
seem to play a central role as to why we are not following the guidelines for the prevention of postsplenectomy sepsis.

Our study has also shown poor adherence to currently accepted post-splenectomy management strategies $(3,4)$. The overall vaccination rate, for pneumococcal vaccine, in our study was $95,24 \%$, which is higher than in most other reports. However, alarmingly, none of the patients from our study have received vaccination for Neisseria meningitides and Haemophilus influenzae. For comparison, one study in Lothian, UK, shows that the vaccination rates for Haemophilus influenzae and Naisseria meningitides were $65.9 \%$ and $48.2 \%$, respectively (5). Even this percentage is considered low and unsatisfactory. Both Neisseria meningitides and Haemophilus influenzae are significant potential pathogens that can cause post-splenectomy sepsis $(6,7)$, and vaccination against these pathogens should be conducted $(8,9,10)$. Another study in Wiltshire, UK, shows that the number of patients who received pneumococcal, meningococcal and Haemophilus influenzae vaccination was 30 out of 76 cases in total $(39,5 \%)$, while the number of patients who did not receive vaccine was 21 out of 76 in total $(27,63 \%)(11)$. These results are still at a very low level, but better than the results from our study ( $0 \%$ of patients received all three vaccines), while percentage of patients who did not receive any recommended vaccine was better (only $4,76 \%$ ). Recent study conducted by Nived et al. showed that the number of patients who have received pneumococcal vaccine is lower than the number of patients in our study $(81 \%)$; however, a larger number of patients received the vaccines against Haemophilus influenzae and meningococcal vaccine $(51,9 \%$ and $22,8 \%$, respectively) (12). The importance of vaccination has also been shown by a study conducted in the USA (13). This study showed that splenectomized patients are at higher risk of pneumonia, meningitis and septicemia, even 10 years after splenectomy (13). It is alarming that none of the doctors (surgeons, general practitioners) knew about the use of vaccines for Neisseria meningitides and Haemophilus influenzae after splenectomy. In the light of these findings, it would be useful to educate a health care team about this problem. It is necessary to increase the awareness of surgeons, epidemiologists and primary care physicians about the risks of postsplenectomy sepsis (14). Clinical/patient education is one of the measures that can significantly reduce the risk of post-splenectomy sepsis (15). Patients should be aware about post-splenectomy risks and importance of vaccination (11). Higher involvement of all relevant structures dealing with treatment of patients who were subjected to splenectomy (primary health care, public health departments, hospitals) is necessary in order to increase the use of vaccines after splenectomy. Education and appropriate vaccination are the factors that may contribute to decreasing a mortality rate (16).

Thus far, it seems that provision of written information, medical alert bracelets and up-to-date vaccination cards to the splenectomized patients has not yet become a part of our current practice. The recommendation for patients is to receive a written information about the post-splenectomy risks, medical alert bracelet and up-to-date vaccination card $(11,17)$. In addition, it is necessary to start using splenectomy registers, because then we will be able to follow up all splenectomized patients and increase the adherence to vaccination (18). Splenectomy status was mentioned in discharge summaries for all forty-seven patients $(100 \%)$, while vaccination status was mentioned for 40 patients $(85,1 \%)$, which is similar to other reports (18). The need for future revaccination or possibility of future post-splenectomy sepsis was not mentioned in discharge summaries or medical files for any patient. In another similar study conducted in Canada, the need for future revaccination was mentioned for $6 \%$ of the patients, and the possibility of post-splenectomy sepsis was mentioned only for 5\% of the patients, which is similar to ours results (18). These results are considered to be unsatisfactory and show that we need to improve administrative procedures.

\section{CONCLUSION}

All the results should be accepted with caution, because we did not interview all the surgeons and general practitioners at the Clinical Centre Pristina, Hospital Centre Kosovska Mitrovica and Community Health Center Gracanica, so we do not know what other doctors might tell us. According to other reports, this study shows that compliance with postsplenectomy prophylaxis needs to be improved. There should be $100 \%$ vaccination rates not only for pneumococcal vaccine but also for meningococcal vaccine and Haemophilus influenzae vaccine, and patients should be discharged with written information and medical alert bracelets. The 
education and awareness of health care team and patients about this problem needs to be upgraded so as to improve the treatment of those patients who have undergone splenectomy.

\section{Acknowledgment}

We thank Dr Dejan Milanovic and Dr Zlatan Elek for their help in compiling this study.

\section{References}

1. Eggink $M$, de Weerdt $O$, Rijkers GT, et al. Vaccination coverage and awareness of infectious risks in patients with an absent or dysfunctional spleen in the Netherland. Vaccine 2008; 26: 6975-9.

http://dx.doi.org/10.1016/j.vaccine.2008.09.052

2. Waghorn DJ. Overwhelming infection in asplenic patients: current best practice preventive measures are not being followed. J Clin Pathol 2001; 54: 214-8.

http://dx.doi.org/10.1136/jcp.54.3.214

3. Styrt B. Infection associated with asplenia: Risks, mechanisms, and prevention. Am J Med 1990; 88: $33 \mathrm{~N}-42 \mathrm{~N}$.

http://www.ncbi.nlm.nih.gov/pubmed/2114797

4. Shaw JHF, Print CG. Postsplenectomy sepsis. Br J Surg 1989; 76: 1074-81.

http://dx.doi.org/10.1002/bjs.1800761029

5. Pickering J, Campbell H. An audit of the vaccination and antibiotic prophylaxis practices amongst patients splenectomized in Lothian. Health Bull (Edinb) 2000; 58: 390-5. http://www.ncbi.nlm.nih.gov/pubmed/12813792

6. Spelman DW. Postsplenectomy overwhelming sepsis: reducing the risks. Med J Aust 1996; 164: 648.

http://www.ncbi.nlm.nih.gov/pubmed/8657024

7. Brigden ML. Overwhelming postsplenectomy infection-Still a problem. West J Med 1992; 157: 440-43.

http://www.ncbi.nlm.nih.gov/pmc/articles/PMC1 011306/

8. Ambrosino DM, Siber GR. Simultaneous administration of vaccines for Haemophilus influenzae type $b$, pneumococci and meningococci. J Infect Dis 1986; 154: 893-96.

http://dx.doi.org/10.1093/infdis/154.5.893

9. Ruben FL, Hankins WA, Zeigler $Z$, et al. Antibody response to meningococcal polysaccharide vaccine in adults without a spleen. Am J Med 1984; 76: 115-121.

http://dx.doi.org/10.1016/0002-9343(84)90759-9

10. Spelman D, Buttery J, Daley A, et al. Guidelines for the prevention of sepsis in asplenic and hyposplenic patients. Intern Med J 2008; 38: 34956.

http://dx.doi.org/10.1111/j.1445-5994.2007.01579.x

11. Ramachandra J, Bond A, Ranaboldo C, Cullis J. An audit of post-splenectomy prophylaxis-are we following the guidelines. Ann R Coll Surg Engl 2003; 85: 252-255.

http://www.researchgate.net/publication/10666966 _An_audit_of_post-splenectomy_prophylaxis__Are_we_following_the_guidelines

12. Nived P, Jorgensen CS, Settergren B. Vaccination status and immune response to 13-valent pneumococcal conjugate vaccine in asplenic individuals. Vaccine 2015; 33: 1699-94 http://dx.doi.org/10.1016/j.vaccine.2015.02.026

13. Kristinsson SY, Gridley G, Hoover RN, et al. Long-term risks after splenectomy among 8149 cancer-free American veterans: a cohort study with up to 27 years follow-up. Haematologica 2014; 99: 392-8.

http://dx.doi.org/10.3324/haematol.2013.092460

14. Williams DN, Kaur B. Postsplenectomy care. Strategies do decrease the risk of infection. Postgrad Med 1996; 100: 195-8, 201, 205.

http://www.ncbi.nlm.nih.gov/pubmed/8668616 
15. White KS, Covington D, Churchill P, et al. Patient awareness of health precautions after splenectomy. Am J Infect Control 1991; 19: 36-41. http://dx.doi.org/10.1016/0196-6553(91)90158-9

16. Sinwar PD. Overwhelming post splenectomy infection syndrome - review study. Int J Surg 2014; 12: 1314-6.

http://dx.doi.org/10.1016/j.ijsu.2014.11.005

17. Jones P, Leder K, Woolley I, Cameron P, Cheng
A, Spelman
D. Postsplenectomy infection-

strategies for prevention in general practice. Aust Farm Physician 2010; 39: 383-6.

http://www.ncbi.nlm.nih.gov/pubmed/20628676

18. Brigden M, Pattullo A, Brown G. Pneumococcal vaccine administration associated with splenectomy: The need for improved education, documentation and the use of practical checklist. Am J Hematol 2000; 65: 25-29. http://dx.doi.org/10.1002/10968652(200009)65:1<25::AID-AJH4>3.0.CO;2-8 


\title{
Razlozi neadekvatne vakcinacije nakon splenektomije
}

\author{
Marko Tanaskovići, Slobodan Janković2,3, Božidar Odalović́, ${ }^{4,5}$ Nedim Hamzagić ${ }^{6}$ \\ ${ }^{1}$ Dom zdravlja Gračanica, Gračanica, Srbija \\ ${ }^{2}$ Klinički centar Kragujevac, Odeljenje za kliničku farmakologiju, Kragujevac, Srbija \\ ${ }^{3}$ Univerzitet u Kragujevcu, Fakultet medicinskih nauka Kragujevac, Kragujevac, Srbija \\ ${ }^{4}$ Klinički centar Priština-Gračanica, Odeljenje za hirurgiju, Gračanica, Srbija \\ ${ }^{5}$ Univerzitet u Prištini, Medicinski fakultet Priština-Kosovska Mitrovica, Kosovska Mitrovica, Srbija \\ ${ }^{6}$ Dom zdravlja Tutin, Odeljenje za nefrologiju, Tutin, Srbija
}

\section{SAŽETAK}

Cilj ove studije bio je da se analiziraju razlozi zbog kojih se ne prate vodiči za postsplenektomijsku vakcinaciju. Imajuću u vidu da vakcinacija smanjuje rizik od ozbiljnih postsplenektomijskih sepsi, važno je da se odrede razlozi za neadekvatne vakcinacije nakon splenektomije.

Naša studija je kvalitativna, bazirana na intervjuima sa šestoro hirurga, jednim lekarom opšte prakse i tri pacijenta koji su bili podvrgnuti splenektomiji, kao i na uvidima u kartone i otpusne liste bolesnika.

Ustanovljeno je da zdravstveni tim i bolesnici imaju nedovoljno znanja o postsplenektomijskoj vakcinaciji. Takođe, ustanovljeno je da splenektomijski registri, medicinske narukvice, kao i karton vakcinacije i dalje nisu deo naše prakse.

Naša studija je pokazala da je obrazovanje bolesnika, kao i medicinskog tima, krucijalno da bi se pratili vodiči za postsplenektomijsku vakcinaciju, što je u skladu sa rezultatima drugih studija.

Kako bi se povećao stepen primene postsplenektomijske vakcinacije, neophodno je poboljšati edukaciju medicinskog tima i bolesnika, kao što je neophodno početi sa korišćenjem splenektomijskih registara, medicinskih narukvica i kartona vakcinacije.

Ključne reči: splenektomija, vakcinacija, kvalitativna, edukacija 